\title{
Successful management of severe liver failure on venoarterial extracorporeal membrane oxygenation using molecular adsorbent recirculating systeme.
}

\author{
Shigeki Tabata \\ Thomas Jefferson University \\ Nicholas Cavarocchi \\ Thomas Jefferson University \\ Hitoshi Hirose \\ Thomas Jefferson University
}

\section{Follow this and additional works at: https://jdc.jefferson.edu/surgeryfp \\ Part of the Surgery Commons \\ Let us know how access to this document benefits you}

\section{Recommended Citation}

Tabata, Shigeki; Cavarocchi, Nicholas; and Hirose, Hitoshi, "Successful management of severe liver failure on venoarterial extracorporeal membrane oxygenation using molecular adsorbent recirculating systeme." (2012). Department of Surgery Faculty Papers. Paper 79.

https://jdc.jefferson.edu/surgeryfp/79

This Article is brought to you for free and open access by the Jefferson Digital Commons. The Jefferson Digital Commons is a service of Thomas Jefferson University's Center for Teaching and Learning (CTL). The Commons is a showcase for Jefferson books and journals, peer-reviewed scholarly publications, unique historical collections from the University archives, and teaching tools. The Jefferson Digital Commons allows researchers and interested readers anywhere in the world to learn about and keep up to date with Jefferson scholarship. This article has been accepted for inclusion in Department of Surgery Faculty Papers by an authorized administrator of the Jefferson Digital Commons. For more information, please contact: JeffersonDigitalCommons@jefferson.edu. 
As submitted to:

Journal of heart and lung transplantation

And later published as:

\author{
Successful management of severe liver failure on veno-arterial \\ extracorporeal membrane oxygenation using molecular adsorbent \\ recirculating system.
}

Dec 2012, Volume 31, Issue(12), pp.1322-3.

doi: 10.1016/j.healun.2012.09.012

Shigeki Tabata, MD, PhD, Nicholas Cavarocchi, MD, Hitoshi Hirose, MD, PhD.

Division of Cardiothoracic Surgery, Department of Surgery

Thomas Jefferson University, Philadelphia, PA, USA

Address reprint requests to Hitoshi Hirose, $\mathrm{MD}, \mathrm{PhD}$.

Division of Cardiothoracic Surgery, Department of Surgery

Thomas Jefferson University

1025 Walnut Street, Room 605, Philadelphia, Pennsylvania 19107, USA

Tel: 1-215-518-4418

Fax: 1-215-955-6010

Email address: genex@nifty.com

Total word count: 672 
A 49-year-old female with Adriamycin induced cardiomyopathy presented with decompensated biventricular congestive heart failure. Despite multiple Inotropes, the patient's hemodynamics deteriorated and she underwent veno-arterial extracorporeal membrane oxygenation (VA-ECMO) placement as a bridge to decision. Pre-ECMO workup showed liver dysfunction with elevated total bilirubin of $5.9 \mathrm{mg} / \mathrm{dl}$, normal liver enzymes and liver ultrasound image. Tentative diagnosis of "end-stage liver failure" was made without a biopsy.

Shortly after initiation of ECMO, the patient developed massive hemoptysis which was successfully managed with continuation of ECMO and ventilator management. ${ }^{1}$ The patient's total bilirubin continued to increase to peak of $56 \mathrm{mg} / \mathrm{dl}$ on ECMO day \#9 (Figure 1). Molecular adsorbent recirculating system (MARS) was initiated on ECMO day 9 thru 14. The bilirubin improved dramatically with MARS. Liver biopsy performed while on ECMO provided a definitive diagnosis of cholestasis without cirrhosis. The patient underwent Heart Mate II left ventricular assist device (LVAD) placement and ECMO removal on ECMO day 20. There was no further episode of liver failure, and the patient was eventually discharged from hospital.

VA-ECMO is a support therapy for the patients with profound cardiac and/or respiratory failure, and its outcomes are closely related with end-organ recovery. ${ }^{2}$ Non-survivors of ECMO follow a common pathway of development of intractable and progressive multi-organ dysfunction. Death can rapidly follow the development of liver dysfunction. Current therapy of liver failure superimposed on cirrhosis is limited to treat the precipitating event; if the precipitating event can be eliminated, the liver can recover to its previous compensated state. Patient with liver failure accumulate toxic molecules and accumulation of these substances may induce encephalopathy, hypotension, renal failure, macrophage dysfunction, and/or inhibition of hepatocyte recovery.

MARS is a cell-free extracorporeal liver support device based on the principle of albumin dialysis. ${ }^{3}$ Blood is perfused through a specific membrane dialyzer that uses $20 \%$ albumin as a 
molecular adsorbent that is re-circulated and perfused in-line through charcoal and anion exchanger columns. Toxic molecules accumulated in the plasma can be eliminated by passage of blood or plasma over sorbent columns since most of these molecules are lipophilic and albumin bound. The molecules which can be removed by MARS include bile acids, conjugated bilirubin, aromatic amino acids, medium chain fatty acids, mercaptans, and cytokines. MARS not only remove selectively albumin bound substances but also MARS will eliminate water soluble toxins such as ammonia, creatinine. ${ }^{3}$ Removal of these toxins by MARS may preserve end organ functions and decreased toxin molecule levels to facilitate organ recovery. ${ }^{4}$

Previously Peek reported that no patient survived from ECMO with MARS if the bilirubin was greater than $23 \mathrm{mg} / \mathrm{dl}(400 \mathrm{umol} / \mathrm{L}) .{ }^{3}$ The peak bilirubin of our patient was 56 $\mathrm{mg} / \mathrm{dl}$ (957 umol/L). A decrease in serum bilirubin for three consecutive days was the primary end point of MARS support on this patient. The bilirubin level remained stable and did not increase after completion of MARS treatment. Liver biopsy confirmed reversible pathology of liver. At this point, this patient's end-organ (liver) dysfunction was resolving. The right ventricular function was recovered while on ECMO and no longer required biventricular support. Chronic left ventricular failure necessitated implantable LVAD. MARS was initiated as a bridge to the decision to LVAD, eliminating elevated bilirubin without adverse effects. Retrospective, the liver dysfunction may have been transient although the peak serum bilirubin level was fatally high. The LVAD implantation was prohibited until hepatic failure was resolved with MARS. 


\section{Disclosure statement}

All of the listed authors indicated no potential conflict of interest. 


\section{References}

${ }^{1}$ Harrison M, Cowan S, Cavarocchi N, Hirose H. Massive hemoptysis on veno-arterial extracorporeal membrane oxygenation. Eur J Cardiothorac Surg. 2012 Mar 30. [Epub ahead of print].

${ }^{2}$ Schwarz B, Mair P, Margreiter J, et al. Experience with percutaneous venoarterial cardiopulmonary bypass for emergency circulatory support. Crit Care Med 2003; 31: 758-64.

${ }^{3}$ Peek GJ, Killer HM, Sosnowski MA, Firmin RK. Modular extracorporeal life support for multiorgan failure patients. Liver. 2002;22:69-71.

${ }^{4}$ El Banayosy A, Kizner L, Schueler V, Bergmeier S, Cobaugh D, Koerfer R. First use of the Molecular Adsorbent Recirculating System technique on patients with hypoxic liver failure after cardiogenic shock. ASAIO J. 2004;50:332-7. 


\section{Legends of Figures}

Figure 1: Total bilirubin was significantly improved after molecular adsorbents recirculating system (MARS) during extracorporeal membrane circulation (ECMO), which was followed by left ventricular assist device (LVAD)

placement.

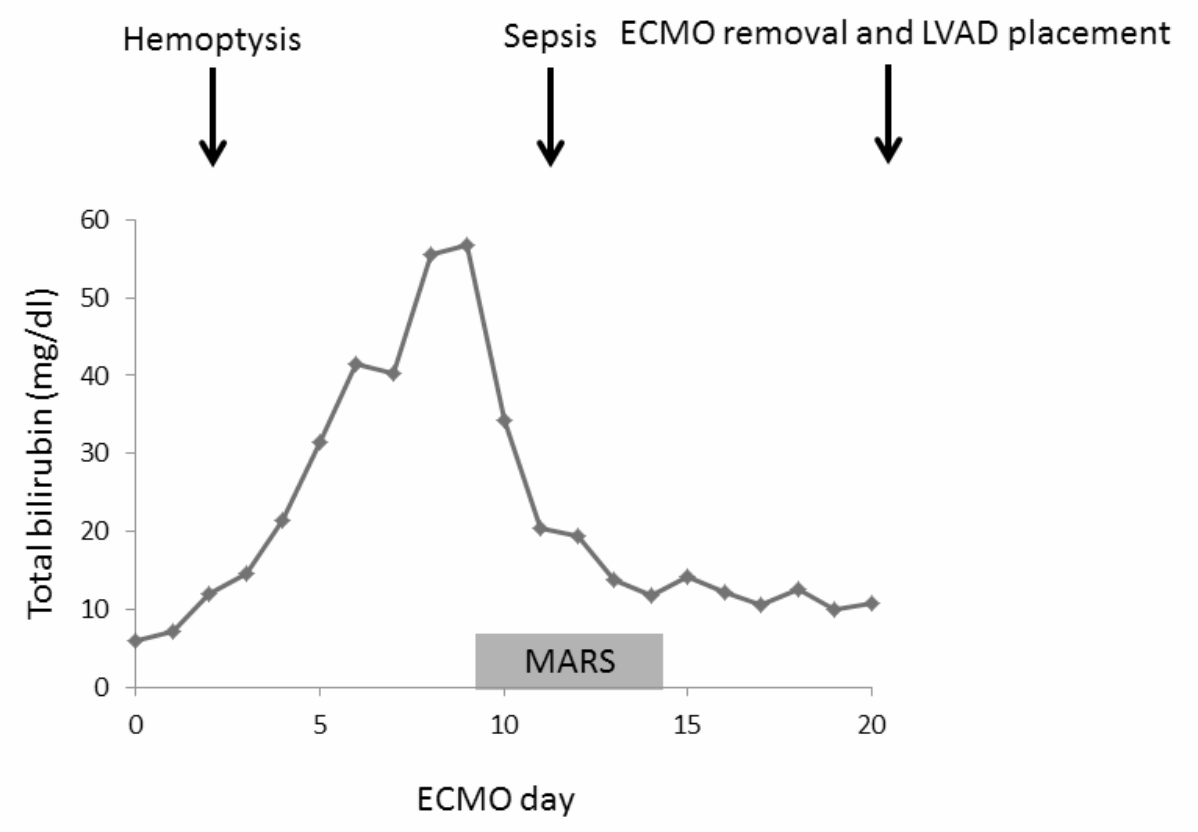

